\title{
Process-based Principles for Restoring River Ecosystems
}

TIMOTHY J. BEECHIE, DAVID A. SEAR, JULIAN D. OLDEN, GEORGE R. PESS, JOHN M. BUFFINGTON, HAMISH

MOIR, PHILIP RONI, AND MICHAEL M. POLLOCK

Process-based restoration aims to reestablish normative rates and magnitudes of physical, chemical, and biological processes that sustain river and floodplain ecosystems. Ecosystem conditions at any site are governed by hierarchical regional, watershed, and reach-scale processes controlling hydrologic and sediment regimes; floodplain and aquatic habitat dynamics; and riparian and aquatic biota. We outline and illustrate four process-based principles that ensure river restoration will be guided toward sustainable actions: (1) restoration actions should address the root causes of degradation, (2) actions must be consistent with the physical and biological potential of the site, (3) actions should be at a scale commensurate with environmental problems, and (4) actions should have clearly articulated expected outcomes for ecosystem dynamics. Applying these principles will help avoid common pitfalls in river restoration, such as creating habitat types that are outside of a site's natural potential, attempting to build static habitats in dynamic environments, or constructing habitat features that are ultimately overwhelmed by unconsidered system drivers.

Keywords: river restoration, ecosystem dynamics, ecosystem processes

n the last century, the world's rivers have been severely

altered by river- and land-management actions that have interrupted fluxes of water, sediment, and nutrients (Dynesius and Nilsson 1994, Ward et al. 1999, Syvitski et al. 2005); simplified the physical structure of habitats and floodplains (Beechie et al. 1994, Hohensinner et al. 2005); and degraded habitat and water quality in river systems by the loading of nutrients and pollutants (Tilman et al. 2001). These changes to watersheds and rivers have altered riverine ecosystems dramatically (Poff et al. 2007), and investments in river restoration over the last few decades have failed to halt declines in habitat quality and ecosystem function (Bernhardt et al. 2005). Moreover, stresses on riverine ecosystems will be exacerbated by steadily rising human demands for water and land, as well as by climate change and shifts in availability of water during seasons when irrigation and ecological demands are high (Postel et al. 1996, Barnett et al. 2005).

Recent calls for national and international river restoration efforts have pressed for more holistic approaches to river management (Palmer and Allan 2006), and for restoration actions that better address primary causes of ecosystem degradation (Kondolf et al. 2006, Roni et al. 2008). However, this recent literature remains fragmented, and the proposed management concepts are still not widely implemented (Palmer et al. 2005, Wohl et al. 2005). Hence, there remains a need to synthesize recently developed concepts in restoration science and practice into a usable set of guiding principles for sustainable river restoration. In this article we define process-based restoration as a means of addressing root causes of degradation, and we characterize the primary processes driving habitat conditions and ecosystem dynamics. We then synthesize recent literature into a set of four fundamental process-based principles for restoring river ecosystems, and explain key analyses needed to implement process-based restoration. Finally, we present several examples to illustrate how process-based restoration actions create more resilient ecosystems than do actions that attempt to create static channel or habitat features.

\section{What is process-based restoration?}

Process-based restoration aims to reestablish normative rates and magnitudes of physical, chemical, and biological processes that create and sustain river and floodplain ecosystems. Processes are typically measured as rates, and they involve the movement of or changes to ecosystem parts and features (Beechie and Bolton 1999). Examples of the processes we discuss include erosion and sediment transport, storage and routing of water, plant growth and successional processes, input of nutrients and thermal energy, and nutrient cycling in the aquatic food web. Process-based restoration, then, focuses on correcting anthropogenic disruptions to these processes, such that the river-floodplain ecosystem progresses along a recovery trajectory with minimal corrective intervention (Sear 1994, Wohl et al. 2005). Restoration of critical processes also allows the system to respond to future perturbations through natural 
physical and biological adjustments, enabling riverine ecosystems to evolve and continue to function in response to shifting system drivers (e.g., climate change).

This approach contrasts with restoration efforts that focus on creating specific habitat characteristics to meet perceived "good" habitat conditions or uniform habitat standards (Wohl et al. 2005, Newson and Large 2006). Such restoration actions favor engineered solutions that create artificial and unnaturally static habitats. These approaches therefore attempt to control processes and dynamics rather than restore them (Beechie and Bolton 1999). Moreover, such actions include channel stability as a criterion for success. By contrast, efforts that reestablish system processes promote recovery of habitat and biological diversity, and include river dynamics (e.g., bank erosion, channel migration, flooding) as criteria for success. Because process restoration focuses on restoring critical drivers and functions, these actions will help avoid common pitfalls of engineered solutions, such as the creation of habitats that are beyond a site's natural potential, piecemeal stabilization of habitat features, and restored habitats that are ultimately overwhelmed by untreated system drivers.

Despite an abundance of research describing the need to restore processes rather than create certain structures, most restoration actions continue to create structures or channel forms that are perceived to be good habitat. Examples of these restoration actions include bank stabilization (including the use of riprap under the guise of habitat restoration); pool or riffle building, using rock weirs and other artificial structures; installation of spawning gravel where none would naturally exist; continual removal of beaver (Castor spp.) dams that are incorrectly perceived to be salmon migration barriers; and the planting of nonnative riparian species (Roni et al. 2008). Beyond such obvious engineering techniques, even actions designed to re-create natural channel forms and habitats can be misapplied when the process context is not considered, including creating channel forms (often symmetrical meanders) that are not suited to local valley slope, sediment supply, or hydrologic regime. Such actions often fail dramatically when modest floods occur (e.g., Kondolf et al. 2001, Palmer et al. 2005). Our purpose in this article is to provide basic principles to help structure the restoration planning process, and to make them simple and practical enough to guide restoration practitioners toward more natural and sustainable restoration actions.

\section{Driving processes and riverine ecosystem dynamics}

Riverine ecosystems are controlled by a suite of hierarchically nested physical, chemical, and biological processes operating at widely varying space and time scales (figure 1, table 1; Sear 1994, Beechie and Bolton 1999). We briefly review the main processes driving riverine habitat dynamics and biota (table 1), focusing on processes commonly disrupted by human land and water uses in order to illustrate use of the processbased principles in habitat restoration.

Landscape-scale processes. The fundamental arrangement of channel forms in a river network is largely controlled
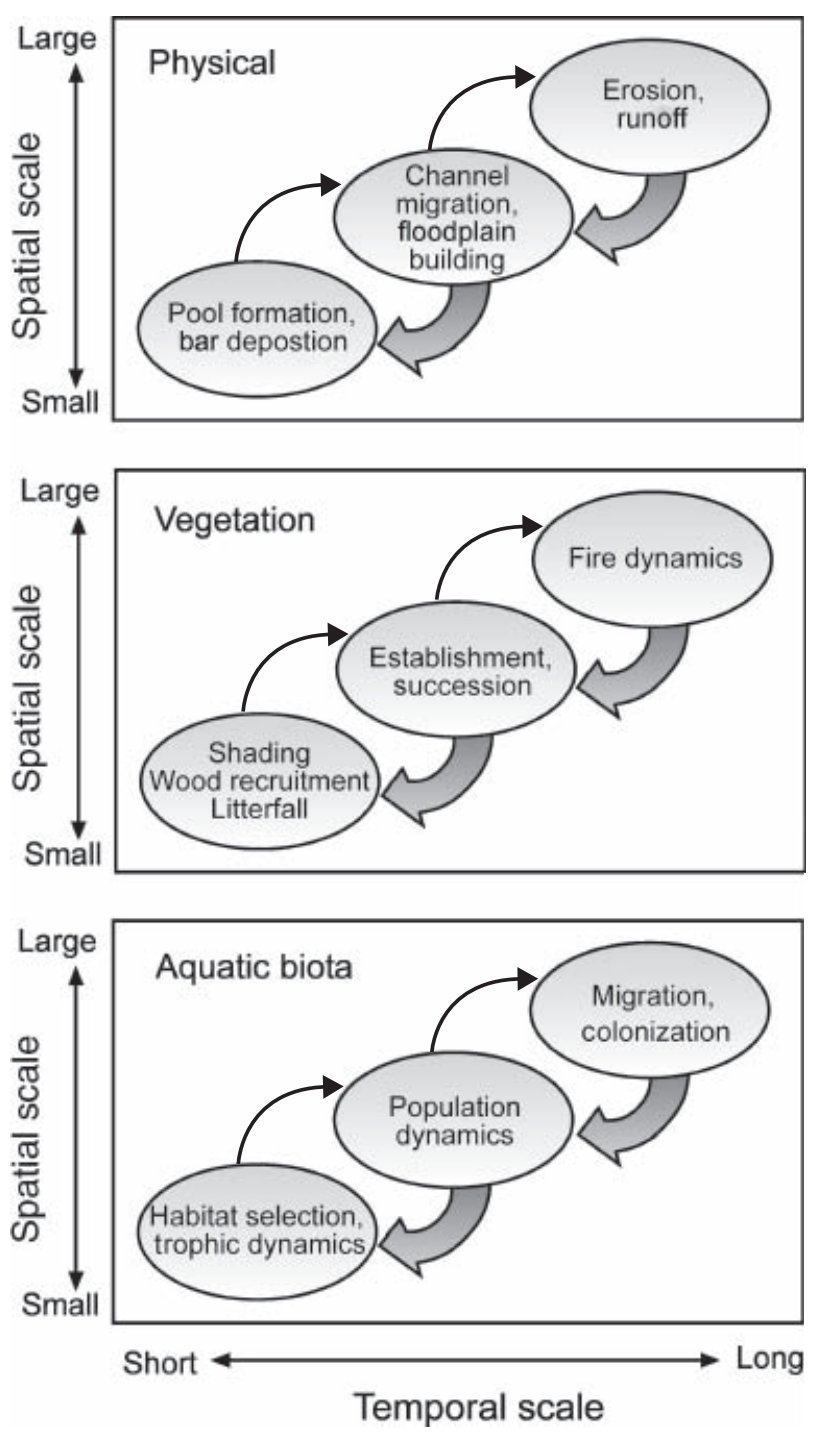

Figure 1. Watershed and ecosystem processes operate at a variety of space and time scales, with processes operating at larger spatial scales generally influencing processes operating at smaller scales (heavy arrows). In some instances, processes operating at smaller scales may also influence processes operating at larger spatial scales (indicated by thin arrows). This is perhaps best illustrated in fishes, where processes such as habitat selection and competition influence survival of individuals, which influences population dynamics at the next larger space and time scale.

by regional geologic and topographic features, collectively referred to as the litho-topographic template (figure 2; Montgomery 1999). This template is essentially fixed over human time frames, as the processes controlling geology and topography (e.g., tectonics) act over centuries to millennia and across large areas (> 100 square kilometers $\left[\mathrm{km}^{2}\right]$ ) to shape the spatial arrangement of channel forms, tributary junctions, and floodplain reaches in a river network (Benda et al. 2004, Stanford et al. 2005). Upon this litho-topographic template, landscape-scale processes operating over smaller space and time scales (e.g., erosion 


\begin{tabular}{|c|c|}
\hline Ecosystem feature & Driving processes \\
\hline \multicolumn{2}{|l|}{ Watershed scale } \\
\hline Sediment & Sediment delivered to river systems through landsliding, surface erosion, and soil creep. \\
\hline Hydrology & Runoff delivered to streams through surface and subsurface flow paths. \\
\hline Organic matter & Tree fall, leaf litter fall. \\
\hline Light and heat & Solar insolation and advective heat transfer to the water column. \\
\hline Nutrients & Delivery of dissolved nutrients via groundwater flow. \\
\hline Chemicals & $\begin{array}{l}\text { Delivery of contaminants, pesticides from agricultural or industrial sites through surface runoff or } \\
\text { shallow subsurface flow. }\end{array}$ \\
\hline Biota & Migration of aquatic organisms, seed transport. \\
\hline \multicolumn{2}{|l|}{ Reach scale } \\
\hline Channel morphology and habitat structure & $\begin{array}{l}\text { Channel migration, bank erosion, bar formation, and floodplain sediment deposition create a dynamic } \\
\text { mosaic of main-channel, secondary-channel, and floodplain environments. Wood recruitment results } \\
\text { in part from bank erosion and channel migration, and wood accumulations reduce bank erosion rates } \\
\text { or enhance island formation. Sediment and wood transport and storage processes drive channel } \\
\text { cross-section shape, formation of pools, and locations of sediment accumulation. Bank reinforcement } \\
\text { by roots reduces bank erosion rates and may force narrowing and deepening of channels. } \\
\text { Animals such as beaver physically modify the environment and create new habitats. }\end{array}$ \\
\hline Thermal regime & $\begin{array}{l}\text { Local stream shading and exchange of water between surface and hyporheic flows regulates stream } \\
\text { temperature at the scale of habitat units and reaches. }\end{array}$ \\
\hline Water chemistry & $\begin{array}{l}\text { Delivery of dissolved nutrients through groundwater and hyporheic exchange; uptake of nutrients } \\
\text { by aquatic and riparian plants. Delivery of pesticides and other pollutants at point sources damage } \\
\text { health and survival of biota. }\end{array}$ \\
\hline Riparian species assemblages & Seedling establishment, tree growth, succession drive reach-scale riparian plant assemblages. \\
\hline Aquatic species assemblages & $\begin{array}{l}\text { Photosynthesis drives primary production of algae and aquatic plants. Leaf-litter inputs drive detritus- } \\
\text { based food web strands. Habitat selection, predation, feeding, growth, and competition drive species } \\
\text { composition of invertebrate, amphibian, and fish assemblages. }\end{array}$ \\
\hline $\begin{array}{l}\text { Note: Watershed-scale processes control del } \\
\text { rounding environment into river channels }\end{array}$ & $\begin{array}{l}\text { of sediment, water, organic matter, nutrients and chemicals, light and heat, and biota from the sur- } \\
\text { oodplains. Channel and floodplain processes at the reach scale rework inputs to channels to determine } \\
\text { ssemblages. }\end{array}$ \\
\hline
\end{tabular}

and runoff) deliver water and sediment to streams, modifying channel conditions and controlling the near-term expression of physical habitat conditions. Erosion and runoff processes such as landsliding, surface erosion, and overland flow are episodic and highly variable from year to year, driven by storm events that occur for periods of hours to days (Benda and Dunne 1997). Over longer time frames, however, consistent sediment and discharge regimes emerge as a result of longer-term climate patterns interacting with the litho-topographic template. Although most river networks exhibit a general downstream trend from steep, sediment-poor channels in headwaters to lowgradient, sediment-rich reaches in the lowlands, transitions between reach types are often abrupt, driven both by tributary junctions and by geological controls that influence channel slope or valley confinement (Benda et al. 2004).

Supply and routing of organic matter (fine particulates to large wood), nutrients, and heat (from sunlight) to river channels can be described in a budgeting framework in which inputs are quantified throughout the river basin, and materials or energy are then routed through the river network. Hence, characterizing inputs of any of the formative components of riverine habitats (water, sediment, organic matter, nutrients, and heat and light) relies on summing many small inputs at individual sites and expressing those sums as rates of delivery from the landscape to the river network or to specific reaches.

Reach-scale processes. At the reach scale, the watershed-scale inputs are reworked by processes operating at smaller space and time scales. Physical habitat dynamics are primarily a function of sediment and water inputs, which drive channel shape, sediment characteristics, and formation of habitat features such as pools and riffles. However, reach-scale processes, such as delivery of wood to the channel or bank reinforcement by roots, also influence physical features, and feedback mechanisms between channels and floodplains modify channel patterns and the arrangement of habitats within reaches. For example, in forested rivers, lateral migration of the channel recruits wood to the river, which then reduces lateral migration and forms floodplain patches that are stable enough to grow large trees, which are ultimately recruited back to the channel to perpetuate the island-braided channel pattern (Gurnell et al. 2001). Delivery of wood to channels can influence 


\section{Reach scale:}

Riparian and channel-

floodplain processes
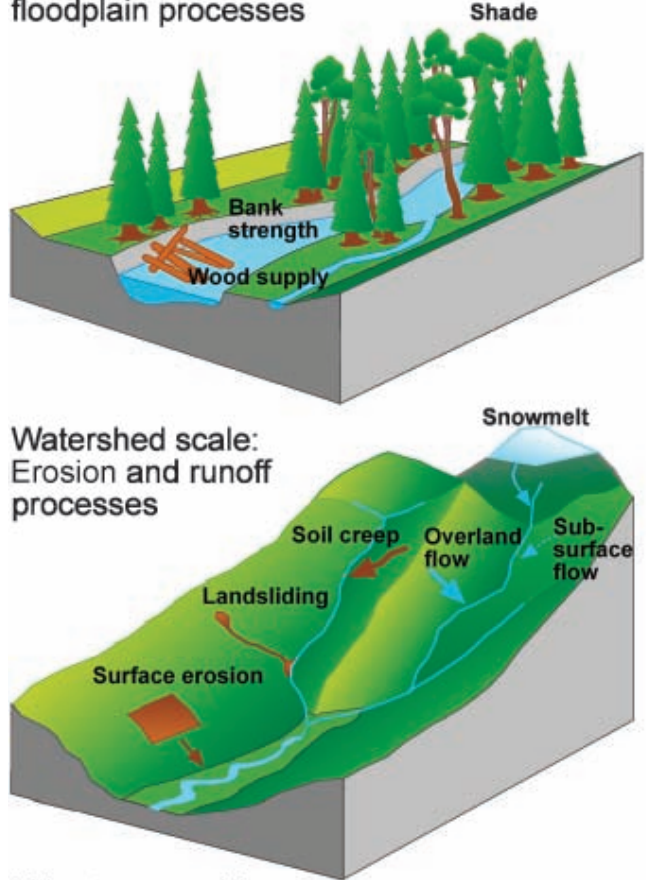

Litho-topographic

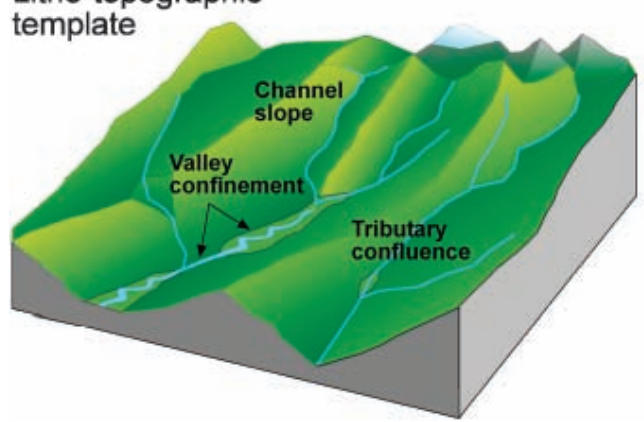

Driving variables controlled by the litho-topographic template: - channel slope - valley confinement

Landscape-scale processes: - tectonics - erosion

Spatial scale of processes: $10^{1} \mathrm{~km}^{2}$

Temporal scale of processes $>10^{3}$ years

Figure 2. Illustration of the hierarchy of processes that control dynamics of habitat features and species assemblages. Selected processes shown here illustrate that the litho-topographic template generally controls slope and valley confinement; watershed-scale processes control discharge and sediment supply; and reach-scale processes control local habitat structure, thermal regimes, and species assemblages.

channel morphology throughout the network, transforming headwater bedrock reaches to alluvial channels, forming pools in midnetwork channels, and forcing island formation and channel switching in large floodplain channels (Abbe and Montgomery 2003). By contrast, in nonforested systems, bank reinforcement by roots is a key influencer of channel form, and beavers initiate channel-floodplain feedbacks in which beaver dams raise the water table and support riparian vegetation, which in turn provides food and materials for future dam construction (Pollock et al. 2007). These processes drive the spatial and temporal dynamics of smaller-scale habitat features, such as formation of new secondary channels on a floodplain or annual shifts in locations of wood and pools, which are an essential, self-renewing property of natural river systems (Jungwirth et al. 2002, Ward et al. 2002).
Water quality and structure of the food web are influenced in part by physical habitat features, but also by inputs of dissolved nutrients, organic matter, and sunlight. Moreover, local nutrient and thermal regimes are partly influenced by physical features, which to some degree control subsurface flow path direction and length, and thereby influence reach-scale processes such as temperature buffering, nutrient cycling, upwelling, and habitat selection by spawning or rearing fishes (Poole et al. 2008). Biological processes that shape ecosystem responses to reach-scale habitat dynamics vary considerably among taxa. Riparian plants, for example, are sessile species driven by two main processes, colonization and succession (Connell 1978, Hughes 1997). The process of colonization (or seedling establishment) allows riparian vegetation to become established on bars and developing floodplains, and succession processes allow those stands to develop into mature forests. When overlain on the dynamic habitat template, these processes lead to predominantly mature vegetation in headwater streams where physical disturbances occur at intervals of several decades or longer, and generally higher diversity of forest ages and species compositions along floodplain channels where physical disturbances occur annually. Notably, riparian vegetation both influences and responds to channel dynamics (as described above for bank strength and wood supply), illustrating the importance of biophysical feedback loops in natural river systems. In contrast to sessile plants, aquatic animals are mainly motile taxa for which the dominant reach-level processes are migration, habitat selection, competition, and predation. As with riparian vegetation, key biophysical feedback loops among animals and physical environments are also important in structuring habitats and supporting dynamic riverine ecosystems (Montgomery et al. 1996, Pollock et al. 2007).

\section{Process-based principles for restoring dynamic river ecosystems}

Many-perhaps most-restoration actions are based on perceptions of "good" or "desirable" habitat types, or on a narrow suite of techniques developed for managing river channels over the past several decades (Roni et al. 2008). This occurs in part because legal mandates such as the US Clean Water Act, US Endangered Species Act, and the European Union Water Framework Directive drive the need to restore narrowly defined aspects of river ecosystems such as water quality, species, or structural features. Unfortunately, these aims or techniques often fail to address root causes of habitat degradation, and therefore restoration projects fail to accomplish the desired environmental and legal objectives. On the basis of a synthesis of recent literature, we propose that such 
Table 2. Summary of the four process-based principles.

\begin{tabular}{|c|c|}
\hline Principle & Description \\
\hline $\begin{array}{l}\text { 1. Target root causes of habitat and } \\
\text { ecosystem change }\end{array}$ & $\begin{array}{l}\text { Restoration actions that target root causes of degradation rely on assessments of processes that } \\
\text { drive habitat conditions, and actions are designed to correct human alterations to those driving } \\
\text { processes. }\end{array}$ \\
\hline $\begin{array}{l}\text { 2. Tailor restoration actions to local } \\
\text { potential }\end{array}$ & $\begin{array}{l}\text { Each reach in a river network has a relatively narrow range of channel and riparian conditions that } \\
\text { match its physiographic and climatic setting, and understanding processes controlling restoration } \\
\text { outcomes helps design restoration actions that redirect channel and habitat conditions into that } \\
\text { range. }\end{array}$ \\
\hline $\begin{array}{l}\text { 3. Match the scale of restoration to } \\
\text { the scale of the problem }\end{array}$ & $\begin{array}{l}\text { When disrupted processes causing degradation are at the reach scale (e.g., channel modification, } \\
\text { levees, removal of riparian vegetation), restoration actions at individual sites can effectively address } \\
\text { root causes. When causes of degradation are at the watershed scale (e.g., increased erosion, } \\
\text { increased runoff due to impervious surfaces), many individual site-scale actions are required to ad- } \\
\text { dress root causes. Recovery of wide-ranging fishes (e.g., Pacific or Atlantic salmon) requires restora- } \\
\text { tion planning and implementation at the scale of population ranges. }\end{array}$ \\
\hline 4. Be explicit about expected outcomes & $\begin{array}{l}\text { Process-based restoration is a long-term endeavor, and there are often long lag times between } \\
\text { implementation and recovery. Ecosystem features will also continuously change through natural } \\
\text { dynamics, and biota may not improve dramatically with any single individual action. Hence, quantify- } \\
\text { ing the restoration outcome is critical to setting appropriate expectations for river restoration. }\end{array}$ \\
\hline
\end{tabular}

problems can be avoided if river restoration actions adhere to four fundamental process-based principles (table 2).

\section{Principle 1: Target the root causes of habitat and ecosystem} change. The core principle of process-based restoration is that restoration actions should address the causes of degradation, rather than the symptoms of it (Beechie and Bolton 1999, Kondolf et al. 2006). Restoration designs often rely on simple habitat or channel evaluations that identify habitat "problems" and are intended to build a specific channel or habitat type perceived as "good." Such actions tend to fail because the design process does not attempt to identify the underlying processes causing habitat degradation, and unaddressed system drivers will ultimately overwhelm the constructed habitat. Examples of this kind of action include the use of wood structures to create pools in a reach where pool loss is primarily a function of levee construction and increased sediment supply, or the use of bank armoring to stop bank erosion, even though bank erosion is a natural process that creates and maintains habitat. Restoration actions that target root causes of degradation are designed to correct human alterations to those driving processes. Hence, the preceding actions would be replaced by actions that set back levees and reduce sediment supply from hill slopes, or that allow bank erosion to occur while reestablishing riparian vegetation across the floodplain.

Principle 2: Tailor restoration actions to local potential. Restoration designs and techniques should be tailored to local physical and biological potential, which are controlled by processes operating at regional, watershed, reach, and site scales. Each reach within a river network has a relatively narrow range of channel and riparian conditions that match its physiographic and climatic setting, and restoration actions should be designed to correct disruptions to driving processes and redirect channel and habitat conditions into that range. Restoration targets consistent with natural potential can be identified through historical analysis and by assessing disruptions to the primary driving processes. For example, analysis of sediment and discharge regimes can be combined with analysis of historical channel patterns to identify appropriate target channel plan forms (e.g., Kondolf et al. 2001). Analyses should also identify human constraints that limit restoration potential and, when necessary, guide restoration designs to be consistent with the altered physical and biological potential (e.g., Trush et al. 2000, Burke et al. 2009). Adhering to this principle will assist restoration planners in identifying appropriate target rates of watershed processes, expected channel and habitat dynamics in the restored system, and anthropogenic constraints that limit restoration potential (e.g., an upstream dam or other infrastructure that will not be moved).

Principle 3: Match the scale of restoration to the scale of physical and biological processes. Successful river restoration will require a broad array of actions at appropriate physical and biological scales that seek to repair processes responsible for ecosystem degradation (Lake et al. 2007). For example, reducing sediment supply to rates near background levels requires actions distributed across a watershed (Kondolf et al. 2006), whereas restoring wood recruitment to a small stream may require only reach-scale restoration of riparian forests (Beechie et al. 2000). Similarly, rebuilding depressed anadromous fish populations (e.g., salmon, lamprey, shad) requires restoration of habitats spanning entire watersheds because the life cycles of these fishes include headwater spawning reaches, midriver spawning and rearing habitats, and delta and estuarine rearing habitats. We acknowledge that this is perhaps the most difficult principle to follow because most restoration actions are at the scale of reaches and smaller, whereas the scales of physical and biological processes that must be addressed are generally at the reach scale and larger (e.g., the watershedscale processes in figure 2). Moreover, the most severe habitat and land-use changes are commonly in lowland floodplains and deltas (Pess et al. 2002, Hohensinner et al. 2005), yet restoration actions most often focus on headwaters and small tributaries (Bernhardt et al. 2005). 
Principle 4: Be explicit about expected outcomes, including recovery time. Process-based restoration is inherently a long-term endeavor, as there are often long lag times between beginning restoration of processes and recovery of certain functions of the river ecosystem (Hughes et al. 2005). For example, riparian plantings may take decades to mature and provide wood to streams, or incised channels may take decades to aggrade after reintroduction of beaver and restoration of natural vegetation (Beechie et al. 2000, Pollock et al. 2007). Hence, quantitative predictions of restoration outcomes are critical to setting appropriate expectations for the magnitude and pace of recovery that will result from restoration actions, estimating how much restoration is needed for ecosystem recovery, and for designing appropriate monitoring and adaptive management programs. Importantly, it is difficult to predict the outcomes of some restoration actions, either because the expected outcome is a dynamic channel with a range of potential conditions, or because future climate change may alter driving processes in unforeseen ways. Nevertheless, even for restoration actions that are intended to restore dynamics, such as channel movement, restoration plans should at least predict the general range of possible outcomes (Perrow et al. 2008, Wheaton et al. 2008).

\section{Applying the process-based principles: Key analyses needed for implementation}

When guided by the four process-based principles, restoration planning is focused on putting the right projects in the right places (following principles 1-3), and on setting appropriate expectations for riverine ecosystem responses to restoration (principle 4). Planning for process-based restoration relies on a suite of analyses that answer two main questions: (1) How have changes in riverine habitats (including their dynamics) affected biota? and (2) What are the ultimate causes of changes in riverine habitats? (figure 3; Beechie et al. 2008a). Answers to these questions identify the causes of degradation that must be addressed (principle 1 ), physical and biological potentials of each reach in a river network (principle 2), and the scales at which restoration actions must be implemented (principle 3). Together, this information identifies which restoration actions are necessary for habitat and ecosystem recovery, as well as reach-specific restoration targets throughout the river network. Once restoration actions are identified, analyses focus on predicting the outcome of restoration actions, including the length of time between action implementation and physical and biological responses (principle 4). These predictions are critical to determining which actions will provide the greatest ecosystem benefit at the least cost, and to assuring realistic expectations for restoration outcomes (Battin et al. 2007).

Identifying necessary restoration actions in a watershed begins with assessments of changes in habitat and biological conditions, as well as assessments of changes to habitatforming processes. Analytical approaches generally include some combination of historical analysis (Hohensinner et al. 2005, Sear and Arnell 2006), reference site data (Karr 1999,

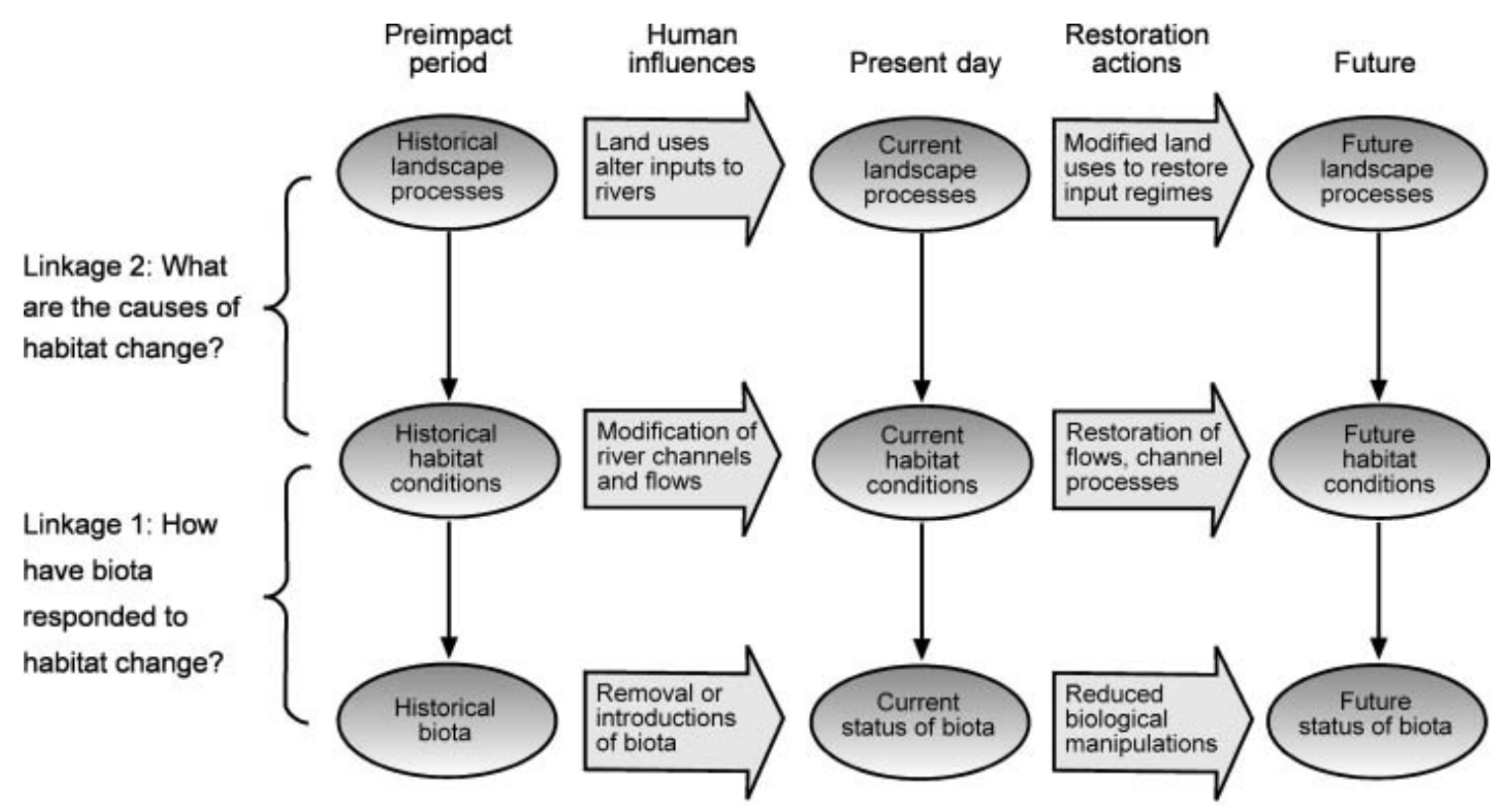

Figure 3. The structure of analyses for planning process-based restoration has a causal linkage dimension (vertical axis), as well as a time dimension (horizontal axis). In this conceptual framework, analyses for restoration planning track linkages between landscape processes, habitat conditions, and biological responses. They also document how human activities have altered riverine ecosystems either by direct manipulation of rivers, floodplains, and biota, or indirectly through changes in driving processes. These analyses guide process-based restoration by identifying causes and scales of degradation (principles 1 and 2), indentifying restoration targets that match local reference rates and conditions (principle 3), and making realistic predictions of restoration outcomes (principle 4). 
Buijse et al. 2002), and model predictions, depending on the availability of information and extant models. Managers can map the causes of habitat change (i.e., changes to watershed- and reach-scale processes) to ensure a clear understanding of magnitudes and locations of process impairments in the watershed (figure $4 \mathrm{a}$ ). Typical analyses include sediment budgets to assess changes in sediment delivery to channels, analyses of shifts in hydrologic regime that are due to land and water uses, changes to riparian vegetation and its influences on riverine habitats, and changes in nutrient and chemical inputs to streams. Barriers to longitudinal connectivity (e.g., dams that disrupt downstream fluxes of water, sediment, and wood, or the upstream migration of fishes) are addressed at point locations, but their effects are assessed as an accumulated change in habitat availability at the watershed scale (Jansson et al. 2007). Habitat analyses estimate both the current and historic (prior to modern intensive river modifications) abundance and quality of each habitat type to quantify the degree to which habitats have changed (figure 4a). In heavily modified landscapes, quantifying changes to habitats usually requires some form of historical analysis because models and reference site data are unable to provide an adequate picture of local potential. Such historical analyses have been conducted in the United States and Europe, where the timing of extensive landscape modification ranges from as recent as 150 years to more than 4500 years ago (Beechie et al. 1994, Brown et al. 2001). Examples of historical analyses include mapping channel forms and historical vegetation patterns from archival maps and surveys, and the characterization of natural habitat conditions from present-day reference sites to estimate past habitat availability in modified sites. Finally, population models (considering the entire life history of targeted biota), multimetric indicators, or other empirical methods are used to assess how habitat changes have affected biota (Beechie et al. 1994, Karr 1999, Poff et al. 2007), and to indicate

\section{a. Selecting actions in a watershed}

Analysis of habitat change and causes relative to reference

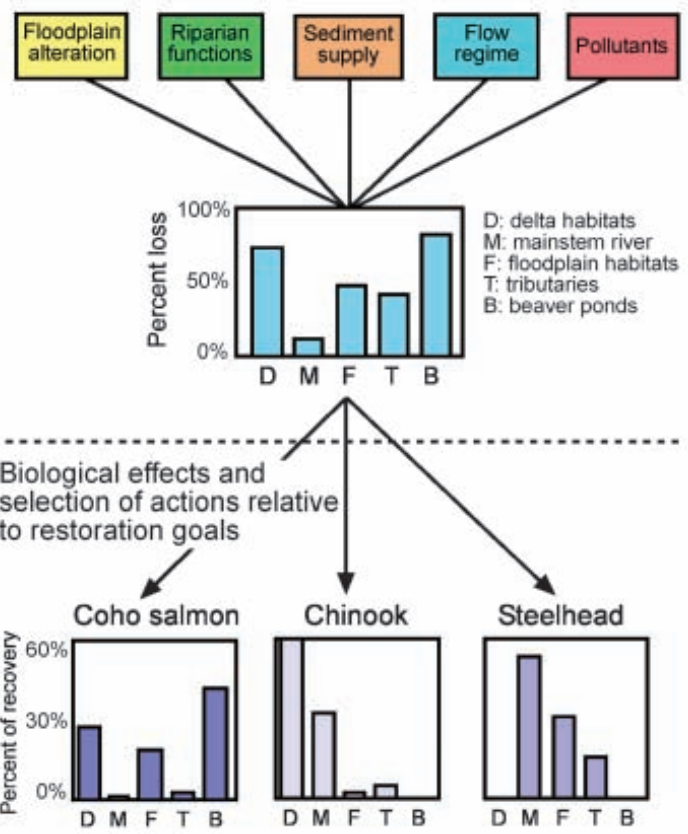

\section{b. Choosing processes to restore at a site}

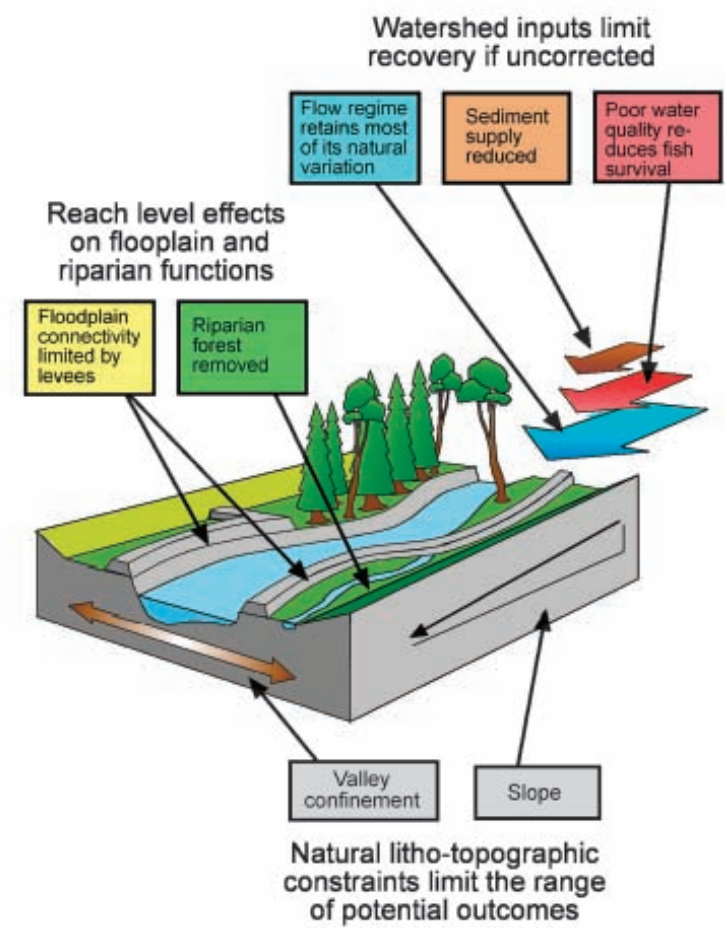

Figure 4. (a) Analyses of habitat losses and changes to watershed processes describe habitat losses in a watershed by location and habitat type (middle bar graph), and maps of causal processes driving the habitat change identify potential restoration actions (illustrated by boxes here; based on Beechie et al. 1994). Priority of restoration actions at the watershed scale is usually driven by restoration goals, which are often driven by legal or policy pressures. Here, legal pressure to restore salmon species would lead to differing priorities depending on life cycles of the species of concern (lower panels). For example, coho salmon restoration depends mainly on restoring delta, floodplain, and beaver pond habitats, whereas steelhead restoration depends mainly on restoring mainstem, floodplain, and tributary habitats. (b) Once actions are selected at the basin scale, selection of processes to restore at each site depends upon the hierarchical nature of disrupted processes (see also figure 2). In this example, local litho-topographic constraints limit restoration potential of floodplain habitats, and reforestation and removal of levees will restore reach-level processes that create mainstem and floodplain habitats. However, reduced sediment supply and poor water quality from upstream will prevent full recovery of the reach if left unaddressed. In general, litho-topographic constraints are fixed, and watershed-scale processes must be restored before reach-scale processes. 
where restoration must take place to restore the river ecosystem. On the basis of these analyses, restoration sites and actions are selected to address the root causes of degradation, but the priority of actions is driven by the relative importance of individual actions to achieving restoration goals (e.g., recovery of specific biota or other river ecosystem attributes) (figure 4a; Beechie and Bolton 1999).

Once a specific restoration site is selected, identifying the root causes of degradation within the site requires more detailed analyses of these same watershed processes, focusing on how they shape local habitat and biological potential (figure $4 \mathrm{~b}$ ). For example, analyses of changes in hydrologic or erosion regimes identify watershed-scale restoration actions necessary to restore the site, whereas analyses of riparian functions or floodplain connectivity identify necessary actions within or adjacent to the site (Hohensinner 2005, Kondolf et al. 2006, Beechie et al. 2008a). Selecting the processes to restore (and to some extent, determining their priority) is based mainly on the hierarchical relationships among disrupted processes that control recovery of the reach. In general, reach-scale processes and conditions cannot be fully restored unless watershed-scale processes are addressed, and litho-topographic controls limit the range of potential restoration outcomes at the reach scale. In the case that some processes may not be restored (e.g., a dam upstream will not be removed and the sediment or hydrologic regime will remain altered), these processes become constraints on restoration (e.g., Trush et al. 2000). Hence, forecasting restoration outcomes includes prediction of future process rates (both restored and unrestored), the lag time between action and response, and a range of plausible outcomes for a river habitat restoration project, rather than a single target end state (Hughes et al. 2005, Sear et al. 2008).

Because complete restoration of watershed and riverine processes is rarely possible (Stanford et al. 1996), river restoration employs strategies ranging from fully restoring processes to habitat-creation efforts that construct artificial habitat features as a substitute for natural functions (table 3). Full-restoration actions restore habitat-forming processes and ultimately return an ecosystem to its predisturbance or normative range of conditions and dynamics. Partial-restoration actions restore selected ecosystem processes and functions, but do not return the system fully to predisturbance conditions and dynamics. Habitat-creation actions are focused on building habitat rather

\begin{tabular}{|ll|}
\hline $\begin{array}{l}\text { Table 3. Definitions of selected classes of restoration actions used in river } \\
\text { management. }\end{array}$ \\
\hline Action class & Definition \\
\hline Full restoration & $\begin{array}{l}\text { Restore processes that create and maintain habitats and biota, } \\
\text { thereby returning a river ecosystem to its normative state. }\end{array}$ \\
Partial restoration & $\begin{array}{l}\text { Restore or improve selected ecosystem processes, thereby } \\
\text { partially restoring a riverine ecosystem. }\end{array}$ \\
Habitat creation & $\begin{array}{l}\text { Improve quality of habitat by treating specific symptoms through } \\
\text { creation of locally appropriate habitat types; used where causes } \\
\text { of degradation cannot be addressed. }\end{array}$ \\
\hline
\end{tabular}

than addressing the root causes of degradation. Given that full restoration is often difficult to achieve even at individual sites, partial restoration frequently becomes the best achievable goal (e.g. Stoddard et al. 2006). Habitat creation should be a last resort because it is typically not self-sustaining (i.e., of short-term value or costly to maintain). Selecting among these types of actions requires policy choices that balance ecological needs against competing socioeconomic demands at individual sites. The role of process-based analyses in this selection process is to help explain the ecological consequences of competing options, and to encourage greater restoration effort through clear illustration of the magnitude of effort needed to restore ecosystem functions. For example, processbased analyses may show that restoration goals cannot be achieved or sustained with habitat-creation efforts alone, and planners might consider new alternatives that remove a greater proportion of human constraints to achieve ecological aims. The balance of these action types across a watershed will likely tend toward full-restoration actions in areas and locations where competing values of land and water used impose few constraints on restoration options. However, in portions of a river basin that are heavily constrained, the balance of action types will likely tend toward habitat construction and partial restoration (figure 5).

\section{Process-based restoration in practice}

Process-based restoration includes a broad suite of techniques, some of which have been available for many years (table 4). However, river engineering techniques that attempt to control processes and dynamics rather than restore them (e.g., bank hardening, channel construction, pool or riffle building) continue to dominate the restoration industry, despite the many examples of failure to achieve ecosystem recovery (Palmer et al. 2005). Here we briefly summarize several examples of process-based restoration to illustrate how following our four principles leads to more sustainable and resilient restoration of riverine ecosystems.

The principles applied to full-restoration actions. Full-restoration actions aim to return a river or part of a river network to its natural regime by restoring natural processes that sustain riverine habitats and biota. We describe two examples of applying the process-based principles to full-restoration actions. The first example is restoration of river-floodplain interactions in the southern United Kingdom, and the second example is a longterm effort to restore an incised stream in the semi-arid region of the Columbia River basin in the United States.

The New Forest LIFE-3 restoration project in southern England seeks to reconnect rivers to their floodplains where past land drainage and channelization resulted in (a) simplification of stream habitats, (b) almost complete disconnection of rivers from their floodplains, and (c) the loss of wet alluvial 


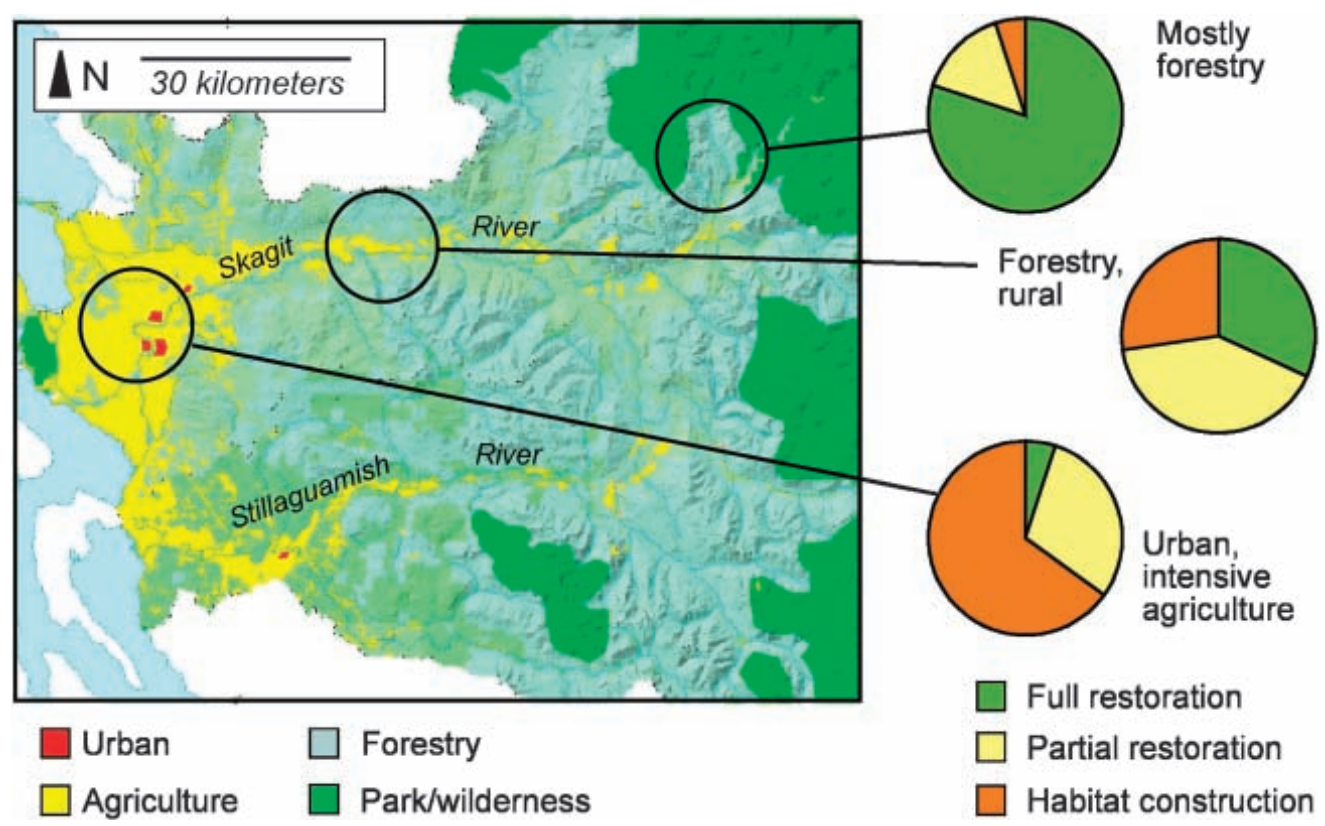

Figure 5. The suite of actions enacted at the watershed scale should be dominated by full-restoration actions (defined in table 3) where land-and water-use constraints are few, but habitat construction actions will be increasingly common in heavily modified areas. In the Skagit and Stillaguamish rivers in the northwestern United States (combined drainage area of 10,040 square kilometers), constraints are most severe in the lower floodplains and deltas where flood-control levees limit restoration options, and actions are dominated by relatively small habitat-construction efforts. The balance of restoration action types is increasingly dominated by full-restoration actions as constraints decrease.

floodplain woodlands (Buijse et al. 2002). The restoration's management goals focused on restoring the physical processes that form pool and riffle sequences in the stream and maintain wet alluvial woodlands on the floodplain. Restoration actions included blocking drainage channels to increase flooding, adding wood structures at natural jam points to form pools and encourage overbank flooding, and removing nonnative trees to afford space and light for recolonizing natural vegetation on the floodplain (Jeffries et al. 2003, Millington and Sear 2007). This restoration action follows the first three principles by addressing the root cause of degradation (channelization and incision), designing the restoration action on the basis of local physical and biological (e.g., riparian species) potential, and initiating actions at the appropriate scale (floodplain scale). Managers identified the expected conditions resulting from restoration (e.g., rates of sediment deposition on the floodplain, frequency and magnitude of overbank flooding, channel morphology, floodplain species composition) by using surveys of relatively unmodified reference reaches (principle 4). One key trade-off in the restoration design was to accept short-term increases in light and stream temperatures (predicted to be higher than reference values for less than 25 years) in order to achieve the longer-term restoration objectives of restoring flooding and native hardwood forests.

Three years after the restoration, all of the hydrological targets have been met, with inundation frequencies, patterns, and processes mimicking those at reference condition sites (Sear et al. 2006). Similarly, floodplain deposition and erosion rates are of comparable magnitude to those found in the reference reaches, as are retention times of wood and sediment. However, the restored reaches initially had larger areas of pool habitat and finer substrate (both caused by the formation of debris dams), but debris dams and area of pools are decreasing as the reach gradually moves toward conditions observed in reference reaches. Continued monitoring of important processes, channel features, and floodplain vegetation recovery will help determine whether the vegetation targets will be successfully met with the current restoration plan, or whether adjustments to the restoration plan may be required (e.g., whether planting of native species might be required to reestablish natural vegetation).

In the second restoration example, the long-term goal is to aggrade more than $30 \mathrm{~km}$ of an incised river channel and reconnect it to its historical floodplain. The channel is currently incised 2 to 5 meters below its historical floodplain (ca. 1880), resulting in a lowered water table, decreased summer flows, higher stream temperature, and sparse or absent riparian vegetation (figure 6; Pollock et al. 2007, Beechie et al. 2008b). The root causes of persistent incision are the loss of beaver dams and channel straightening, both of which prevent this sediment-rich system from aggrading. Analysis of sediment-retention processes at reference sites showed that mean aggradation rates with beaver dams are 7.5 centimeters per year (Pollock et al. 2007), and also that beaver dams in the incised stream trench fail frequently because the narrow trench increases flood heights over the dams. In the few reaches where inset floodplains exist, beavers build wider 
Table 4. Examples of process-based restoration actions designed to correct causes of ecosystem degradation at both watershed and reach scales, or to restore migration pathways.

\begin{tabular}{|c|c|c|}
\hline Cause of degradation & Restoration action & Purpose \\
\hline \multicolumn{3}{|l|}{ Watershed scale } \\
\hline $\begin{array}{l}\text { Increased surface erosion and } \\
\text { sediment delivery }\end{array}$ & Resurface or remove forest roads & $\begin{array}{l}\text { Reduce erosion of fine sediments, and reduce delivery } \\
\text { of fine sediments to streams }\end{array}$ \\
\hline $\begin{array}{l}\text { Flow regulation has reduced peak } \\
\text { and low flows }\end{array}$ & Environmental flow restoration & $\begin{array}{l}\text { Restore a range of critical flows, including } \\
\text { channel-forming flows, maintenance flows, and low flows }\end{array}$ \\
\hline \multicolumn{3}{|l|}{ Reach scale } \\
\hline $\begin{array}{l}\text { Levees prevent flooding and } \\
\text { secondary-channel habitat formation }\end{array}$ & Levee set-back or removal & $\begin{array}{l}\text { Restore lateral channel migration, floodplain patch turnover, } \\
\text { riparian forest succession, habitat diversity, movement of biota }\end{array}$ \\
\hline $\begin{array}{l}\text { Loss of wood delivery and stream } \\
\text { shading }\end{array}$ & Replant or thin riparian forests & $\begin{array}{l}\text { Restore wood recruitment, restore shade functions, } \\
\text { restore nutrient inputs }\end{array}$ \\
\hline $\begin{array}{l}\text { Loss of in-channel sediment } \\
\text { retention prevents recovery of } \\
\text { incised channels }\end{array}$ & $\begin{array}{l}\text { Reintroduce beaver to help } \\
\text { aggrade incised river channels }\end{array}$ & $\begin{array}{l}\text { Restore natural sediment retention mechanism, accelerate } \\
\text { aggradation, raise water table, and increase spatial extent } \\
\text { of riparian vegetation }\end{array}$ \\
\hline \multicolumn{3}{|l|}{ Habitat connectivity } \\
\hline $\begin{array}{l}\text { Dams block fish access to } \\
\text { spawning and rearing habitats }\end{array}$ & $\begin{array}{l}\text { Remove dams or build passage } \\
\text { structures }\end{array}$ & $\begin{array}{l}\text { Restore ability of fishes to migrate among habitats that } \\
\text { are critical to their life cycles }\end{array}$ \\
\hline
\end{tabular}

dams which disperse the high flow, and these colonies have persisted for decades. Based on these analyses, experimental restoration efforts aim to aggrade the channel and increase sinuosity by increasing the number and longevity of beaver dams, which should lead to improved riparian condition, expanded beaver populations, and, ultimately, more rapid aggradation of the channel. The primary restoration actions include riparian revegetation to increase habitat capacity for local beaver populations, and the use of small wood posts to support beaver dams during high flows and encourage beaver population expansion. Initial results show increased aggradation and sinuosity at supported dams and decreased dam failures during floods. Experimental installation of dam support posts in reaches more than $5 \mathrm{~km}$ from the nearest beaver dam also initiated beaver colonization within a few months, indicating the potential to expand the spatial extent of aggradation in the reach by accelerating aggradation and widening of the inset floodplain. All of the dam sites have experienced rapid aggradation matching rates observed in reference sites (Pollock et al. 2007). Monitoring of beaver dam number and longevity, aggradation rates, water table elevation, and riparian conditions will indicate whether beaver populations are expanding, and whether biophysical feedbacks between beaver dam construction, water table elevations, and riparian vegetation are recovering. A critical element of this experiment is that installation of support structures will cease as soon as ecosystem processes are on a steady recovery trajectory. Ultimately, reconnecting the stream to its historical floodplain through the recovery of beaver populations will take decades, but without these actions recovery will take centuries to millennia (Beechie et al. 2008b). This restoration action follows the first three principles by (1) addressing the root causes preventing aggradation, (2) targeting a natural reference condition, and (3) restoring at a scale that will allow the system to sustain itself. Finally, the restoration effort has clearly described expected outcomes (principle 4), including estimated recovery times for incised channels.

The principles applied to partial-restoration actions. Partialrestoration actions aim to restore only selected physical, chemical, or biological processes, and are perhaps the most common class of restoration actions. A common example of such actions is the growing number of river-restoration projects that focus on managing flow regimes to improve ecosystem health in dammed rivers (Bednarek and Hart 2005, Richter and Thomas 2007). The goal of these efforts is to create an environmental flow regime that mimics essential components of the natural hydrograph, including the magnitude and seasonal pattern of peak flows and low flows (Stanford et al. 1996, Poff et al. 1997). Although the multiple, competing objectives imposed on any water management system make it impossible to maintain the full spectrum of naturally occurring flows in a river, managing the release schedule of dams to support critical facets of the flow regimes is a strategy to mitigate the ecological effects of dams (Arthington et al. 2006, Richter et al. 2006). These actions address one root cause of ecosystem decline by restoring elements of the local natural hydrologic regime (principles 1 and 2), and they are implemented at an appropriate scale (principle 3). Expected outcomes are predicted on the basis of known relationships between flows and biota (principle 4), recognizing that a naturally variable regime of river flow is required to support freshwater ecosystem functions (Tharme 2003). One example of environmental flow restoration is on the Bill Williams River, Arizona, for which conceptual flow-ecology models for diverse taxaincluding aquatic macroinvertebrates, fishes, riparian plants, 
a

Wet floodplain system:

- sedge meadows

- deep accumulation of sediments

- elevated water table

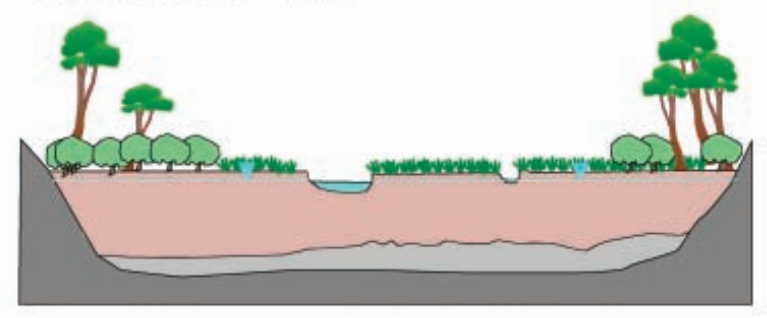

Incised channel:

- conversion to xeric vegetation

- lowered water table

- intermittent streamflow

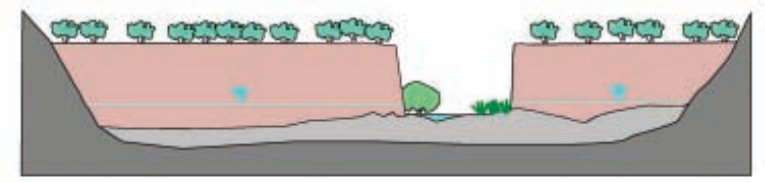

b

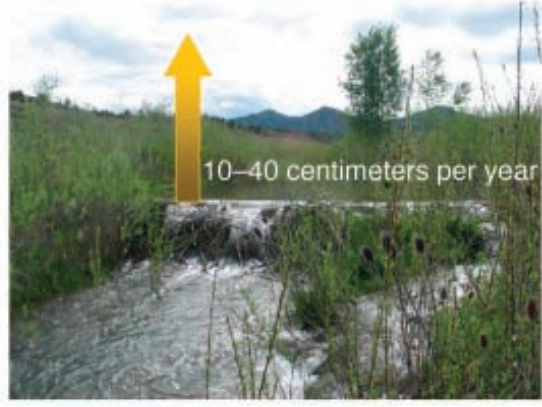

C

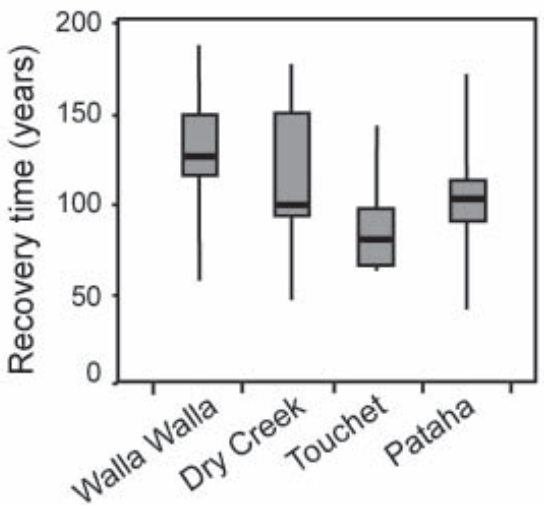

Figure 6. Applying the process-based principles to incised channel restoration in the northwestern United States identified that (1) loss of sediment retention mechanisms was the primary process inhibiting recovery; (2) the reach scale is the appropriate scale for addressing sediment retention; (3) restoration of beaver populations, raised water tables, and dense riparian vegetation is consistent with historical descriptions of the natural potential of the site; and (4) reconnection of channels to their historical floodplains will raise the riparian water table and reestablish riparian vegetation. (a) Channel incision has shifted river ecosystems from wet meadow and forest ecosystems with stable stream flow to intermittent streams bordered by xeric, upland vegetation. (b) Sediment retention by beaver dams averages 7.5 centimeters (cm) per year, but can be as high 10 to $40 \mathrm{~cm}$ per year (Pollock et al. 2007). (c) Recovery time for incised channels ranges from 50 to 180 days depending on degree of incision, sediment supply, and sediment retention (Beechie et al. 2008b).

and terrestrial fauna-have been developed (Shafroth and Beauchamp 2006). These conceptual models relate the magnitude, timing (season), duration, frequency, and rate of change of flood flows and base flows associated with particular ecological processes or functions (figure 7). A series of experimental high-flow events from 2006 to 2008 were released from the Alamo Dam, the results of which supported the development of physical process models linking stream flow, river stage, and riparian tree seedling establishment requirements. These models are now used to predict relations between flow, geomorphic processes, and biotic responses such as beaver dam and vegetation persistence, which will then be used in setting environmental flow targets.

A second example of implementing process-based partial restoration is restoring longitudinal connectivity within a stream by eliminating widespread barriers to fish migration (Yanes et al. 1995, Langill and Zamora 2002). Such projects focus on repairing a single type of disruption to river ecosystem functions, but do not address other processes affecting either habitat or biological conditions in the river system. Hence, they are partial-restoration actions because they restore only selected components of the river ecosystem.
Nevertheless, these projects also follow the four processbased principles by addressing the root cause of reduced species ranges (principle 1); tailoring actions to local potential, where the potential is the ability of organisms to occupy diverse habitats in a river network (principle 2); and taking actions at the scale of population dynamics (principle 3). Lastly, the expected outcomes (principle 4) can be calculated relatively easily because fish migration is restored immediately and habitat capacities can be used to estimate biological outcomes of restoring connectivity (Beechie et al. 1994, Pess et al. 2005). A widely used restoration technique is fish-passage restoration through culverts and tide gates. Roads, culverts, levees, pipeline crossings, and other manmade stream-crossing structures can block access for aquatic fauna, and can biologically disconnect large amounts of critical habitat from the river system. For example, migration barriers prevent migratory fishes from accessing their spawning grounds in small streams, limiting the upstream extent of habitat used and reducing the amount of marinederived nutrients introduced into a river system (Gende et al. 2002). Such structures can also compromise delivery of materials, including sediment, wood, organics, and 

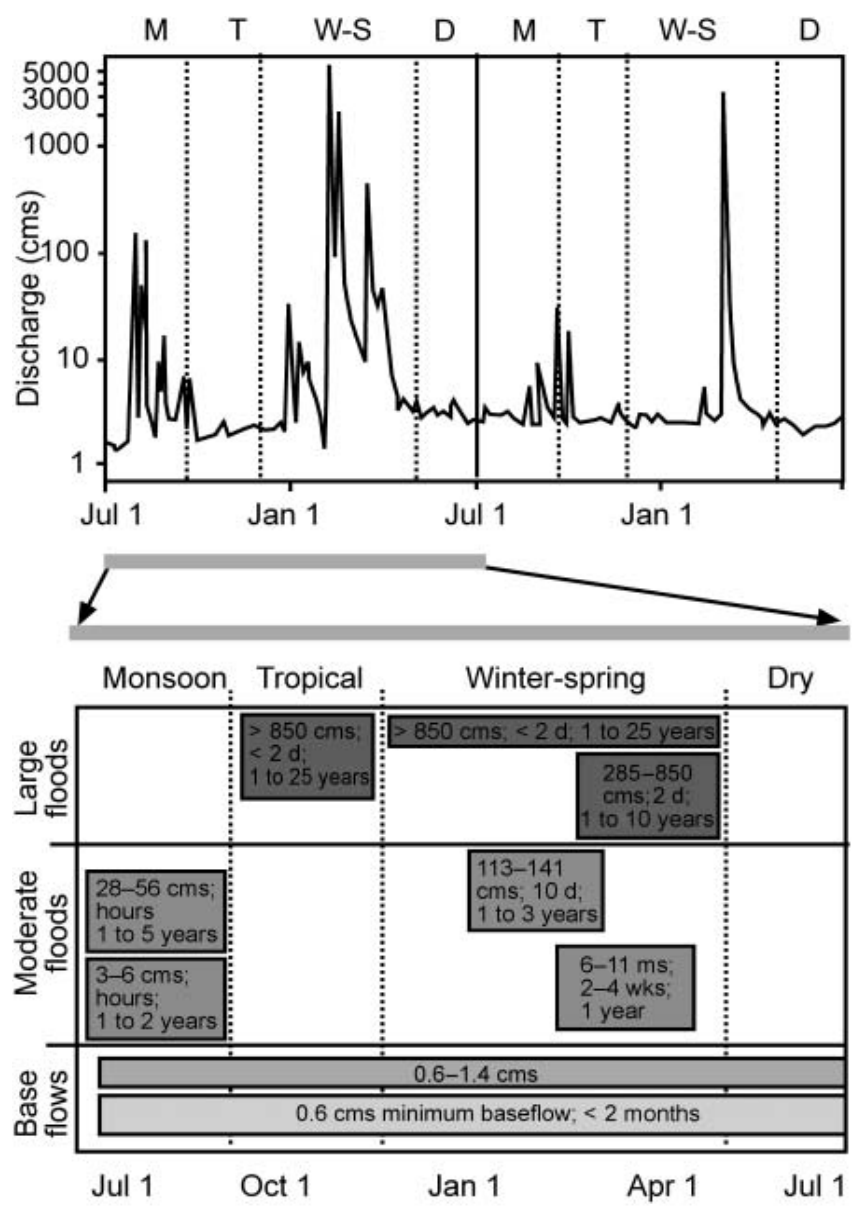

Key functions of selected target flows


-create off-channel habitat

\section{Moderate floods}

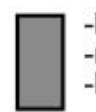

-herbacecous growth

-native fish spawning

-litter decomposition

Base
flows

$\square \begin{aligned} & \text {-maintain aquatic habitat } \\ & \text {-maintain established riparian vegetation } \\ & \text {-favor native species }\end{aligned}$

Figure 7. Application of process-based principles to partially restore stream flows based on the natural hydrograph of the Bill Williams River in Arizona, United States. Stream flow restoration targets one cause of degradation (altered flow regime) at appropriate time and space scales, is based on the natural hydrograph for the site, and includes predicted outcomes for each component of the flow prescription. The upper panel shows two contrasting flow years from the predam hydrograph; $D$, dry season; $M$, monsoon season; T, tropical season; $W-S$, winter-spring season. Middle panel shows selected flow targets by season; each box includes flow magnitude, flow duration, and frequency. The lower panel shows examples of predicted outcomes for each flow range. Source: Shafroth and Beauchamp (2006). Discharge is expressed in cms, cubic meters per second. marine-derived nutrients, or, in the case of estuarine and off-channel habitats, the influx of water and nutrients.

The principles applied to habitat creation. Habitat creation is by definition not process based, as it focuses on treating symptoms of degradation rather than causes, and most commonly involves construction of specific habitat features. Nevertheless, habitat creation is an important component of river-management strategies because it is often impossible to implement the restoration of processes (e.g., channel migration) in heavily developed portions of riverine landscapes (see also figure 5). Therefore, improving ecosystem functions in developed areas relies on the careful design and placement of created habitats, and maximally applying the process-based principles will improve their suitability, function, and persistence. However, the first principle is rarely applied because habitat creation usually does not address the root cause of degradation. The remaining principles guide the creation of habitats that are consistent with local natural potential (principle 2), and that are at relevant spatial and temporal scales (principle 3). Predicted outcomes are usually based on comparisons with similar actions in other locations, or on the evaluation of the natural habitats that habitat creation attempts to mimic (principle 4). A commonly used habitat-creation technique is the reintroduction of wood to river systems, an approach that focuses on the treatment of a symptom (wood and pool losses) rather than a cause of habitat degradation (reduced riparian function). When the process-based principles are applied to habitat creation using wood placement, structural designs are on the basis of naturally occurring logjams to increase longevity and to assure that they function similarly to natural jams (e.g., Abbe and Montgomery 2003, Brooks et al. 2004). Typical functions of wood in streams include scouring of deep pools, creating rearing habitat for fishes, and providing organic substrates to increase local invertebrate production (Coe et al. 2009). Such actions can also contribute to broader river-floodplain restoration goals if the objective of largewood placement is for the structures to persist until natural wood recruitment recovers following simultaneous restoration of the riparian corridor.

Similarly, the process-based principles can be applied to construction of secondary-channel habitats where channel floodplain interactions have been lost. In this case, the principles guide project designs toward secondary-channel habitats that mimic the types of habitats historically available, and that are implemented at the scale of natural river and floodplain features. However, the habitat-forming processes (channel migration, floodplain erosion and deposition, and secondary channel formation) are not restored, and the created habitats are static imitations of habitat types that could naturally exist in the setting.

\section{Conclusions}

River ecosystems are driven by a hierarchical suite of physi$\mathrm{cal}$, chemical, and biological processes, and process-based 
restoration aims to restore these drivers of ecosystem function and dynamics. Such actions restore river dynamics and natural variation in habitat conditions, which are inherently more sustainable and resilient than engineered channels or habitats. Actions that restore natural processes require minimal maintenance over time, and allow physical or chemical habitat attributes and biota to adjust to long-term stresses such as climate change. Moreover, such actions restore multiple ecosystem components concurrently, which means they can simultaneously address multiple regulatory objectives such as the Habitats and Water Framework Directives in the European Union, or the Clean Water and Endangered Species Acts in the United States. Our four process-based principles guide restoration at both reach and watershed scales to shift river restoration toward actions that address root causes of degradation and promote the sustainable recovery of dynamic river ecosystems. However, the challenge of restoring driving processes increases with river size because larger rivers accumulate a larger number and wider variety of disturbances within their watersheds. Moreover, restoration constraints typically increase in larger rivers, as river regulation by large dams or infrastructure development for navigation and commerce pose significant barriers to restoration. Restoration of ecosystem functions in large rivers requires identifying how restoration actions should be implemented in concert with one another to cumulatively affect the larger-scale function of the system. Likewise, determining the best locations for effective restoration actions within the basin requires a clear understanding of tradeoffs between ecological benefits of restoration actions and competing human demands for goods and services derived from rivers.

\section{Acknowledgments}

We thank Casimir Rice, Aimee Fullerton, and three anonymous reviewers for helpful critique and review of this article.

\section{References cited}

Abbe TB, Montgomery DR. 2003. Patterns and processes of wood debris accumulation in the Queets River basin, Washington. Geomorphology 51: 81-107.

Arthington AH, Bunn SE, Poff NL, Naiman RJ. 2006. The challenge of providing environmental flow rules to sustain river ecosystems. Ecological Applications 16: 1311-1318.

Barnett TP, Adam JC, Lettenmaier DP. 2005. Potential impacts of a warming climate on water availability in snow-dominated regions. Nature 438: 303-309.

Battin J, Wiley MW, Ruckelshaus MH, Palmer RN, Korb E, Bartz KK, Imaki H. 2007 Projected impacts of climate change on salmon habitat restoration. Proceedings of the National Academy of Sciences 104: 6720-6725.

Bednarek AT, Hart DD. 2005. Modifying dam operations to restore rivers: Ecological responses to Tennessee River dam mitigation. Ecological Applications 15: 997-1008.

Beechie TJ, Bolton S. 1999. An approach to restoring salmonid habitatforming processes in Pacific Northwest watersheds. Fisheries 24: 6-15.

Beechie TJ, Beamer E, Wasserman L. 1994. Estimating coho salmon rearing habitat and smolt production losses in a large river basin, and implications for habitat restoration. North American Journal of Fisheries Management 14: 797-811.
Beechie TJ, Pess G, Kennard P, Bilby RE, Bolton S. 2000. Modeling recovery rates and pathways for woody debris recruitment in northwestern Washington streams. North American Journal of Fisheries Management 20: 436-452.

Beechie TJ, Pess G, Roni P, Giannico G. 2008a. Setting river restoration priorities: A review of approaches and a general protocol for identifying and prioritizing actions. North American Journal of Fisheries Management 28: 891-905.

Beechie TJ, Pollock MM, Baker S. 2008b. Channel incision, evolution and potential recovery in the Walla Walla and Tucannon River basins, northwestern USA. Earth Surface Processes and Landforms 33: 784-800.

Benda L, Dunne T. 1997. Stochastic forcing of sediment supply to channel networks from landsliding and debris flow. Water Resources Research 33: 2865-2880.

Benda L, Poff L, Miller D, Dunne T, Reeves G, Pess GR, Pollock MM. 2004. The network dynamics hypothesis: How channel networks structure riverine habitats. BioScience 54: 413-427.

Bernhardt ES, et al. 2005. Synthesizing US river restoration efforts. Science 308: 636-637.

Brooks AP, Gehrke PC, Jansen JD, Abbe TB. 2004. Experimental reintroduction of woody debris on the Williams River, NSW: Geomorphic and ecological responses. River Research and Applications 20: 513-536.

Brown AG, Cooper L, Salisbury CR, Smith DN. 2001. Late Holocene channel changes of the Middle Trent: Channel response to a thousand-year flood record. Geomorphology 39: 69-82.

Buijse AD, Coops H, Staras M, Jans LH, Van Geest GJ, Grifts RE, Ibelings BW, Oosterberg W, Roozen FCJM. 2002. Restoration strategies for river floodplains along large lowland rivers in Europe. Freshwater Biology 47: 889-907.

Burke M, Jorde K, Buffington JM. 2009. Application of a hierarchical framework for assessing environmental impacts of dam operation: Changes in hydrology, channel hydraulics, bed mobility and recruitment of riparian trees in a western North American river. Journal of Environmental Management: S224-S236.

Coe H, Kiffney P, Pess GR, Kloehn K, McHenry M. 2009. Periphyton and invertebrate response to wood placement in large pacific coastal rivers. River Research and Applications 25: 1025-1035.

Connell JH. 1978. Diversity in tropical rain forests and coral reefs. Science 199: 1302-1310.

Dynesius M, Nilsson C. 1994. Fragmentation and flow regulation of rivers systems in the northern third of the world. Science 266: 753-762.

Gende SM, Edwards RT, Willson MF, Wipfli MS. 2002. Pacific salmon in aquatic and terrestrial ecosystems. BioScience 52: 917-927.

Gurnell AM, Petts GE, Hannah DM, Smith BPG, Edwards PJ, Kollmann J, Ward JV, Tockner K. 2001. Riparian vegetation and island formation along the gravel-bed Fiume Tagliamento, Italy. Earth Surface Processes and Landforms 26: 31-62.

Hohensinner S, Jungwirth M, Muhar S, Habersack H. 2005. Historical analyses: A foundation for developing and evaluating river-type specific restoration programs. International Journal of River Basin Management 3: 1-10.

Hughes FMR. 1997. Floodplain biogeomorphology. Progress in Physical Geography 21: 510-529.

Hughes FMR, Colston A, Mountford JO. 2005. Restoring riparian ecosystems: The challenge of accommodating variability and designing restoration trajectories. Ecology and Society 10: 12. (31 December 2009; www.ecologyandsociety.org/vol10/iss1/art12/)

Jansson R, Nilsson C, Malmqvist B. 2007. Restoring freshwater ecosystems in riverine landscapes: The roles of connectivity and recovery processes. Freshwater Biology 52: 589-596.

Jeffries R, Darby SE, Sear DA. 2003. The influence of vegetation and organic debris on floodplain sediment dynamics: A case study of a low-energy stream in the New Forest, Hampshire. Geomorphology 51: 61-80.

Jungwirth M, Muhar S, Schumtz S. 2002. Re-establishing and assessing ecological integrity in riverine landscapes. Freshwater Biology 47: 867-887.

Karr JR. 1999. Defining and measuring river health. Freshwater Biology 41: 221-234. 
Kondolf GM, Smeltzer MW, Railsback SF. 2001. Design and performance of a channel reconstruction project in a coastal California gravel-bed stream. Environmental Management 28: 761-776.

Kondolf GM, et al. 2006. Process-based ecological river restoration: Visualizing three-dimensional connectivity and dynamic vectors to recover lost linkages. Ecology and Society 11: 5. (31 December 2009; www.ecology andsociety.org/vol11/iss2/art5/)

Lake PS, Bond N, Reich P. 2007. Linking ecological theory with stream restoration. Freshwater Biology 52: 597-615.

Langill DA, Zamora PJ. 2002. An Audit of Small Culvert Installations in Nova Scotia: Habitat Loss and Habitat Fragmentation. Canadian Technical Report of Fisheries and Aquatic Sciences 2422.

Millington CE, Sear DA. 2007. Impacts of restoration on small wood dynamics in a low gradient headwater stream. Earth Surface Processes and Landforms 37: 121-133.

Montgomery DR. 1999. Process domains and the river continuum. Journal of the American Water Resources Association 35: 397-410.

Montgomery DR, Buffington JM, Peterson P, Scheutt-Hames D, Quinn TP. 1996. Streambed scour, egg burial depths and the influence of salmonid spawning on bed surface mobility and embryo survival. Canadian Journal of Fisheries and Aquatic Sciences 53: 1061-1070.

Newson MD, Large ARG. 2006. 'Natural' rivers, 'hydromorphological quality' and river restoration: A challenging new agenda for applied fluvial geomorphology. Earth Surface Processes and Landforms 31: 1606-1624.

Palmer MA, Allan JD. 2006. Restoring rivers. Issues in Science and Technology (Winter): 40-48.

Palmer MA, et al. 2005. Standards for ecologically successful river restoration. Journal of Applied Ecology 42: 208-217.

Perrow MR, Skeate ER, Leeming D, England J, Tomlinson ML. 2008. Uncertainty surrounding the ecological targets and response of river and stream restoration. Pages 139-166 in Darby SE, Sear DA, eds. River Restoration: Managing the Uncertainty in Restoring Physical Habitat. Wiley.

Pess GR, Montgomery DR, Beechie TJ, Holsinger L. 2002. Anthropogenic alterations to the biogeography of salmon in Puget Sound. Pages 129154 in Montgomery DR, Bolton S, Booth DB, Wall L, eds. Restoration of Puget Sound Rivers. University of Washington Press.

Pess GR, Morley SA, Roni P. 2005. Evaluating fish response to culvert replacement and other methods for reconnecting isolated aquatic habitats. Pages 267-276 in Roni P, ed. Methods for Monitoring Stream and Watershed Restoration. American Fisheries Society.

Poff NL, Allan JD, Bain MB, Karr JR, Prestegaard KL, Richter BD, Sparks RE, Stromberg JC. 1997. The natural flow regime: A paradigm for river conservation and restoration. BioScience 47: 769-784.

Poff NL, Olden JD, Merritt MD, Pepin DM. 2007. Homogenization of regional river dynamics by dams and global biodiversity implications. Proceedings of the National Academy of Sciences 104: 5732-5737.

Pollock MM, Beechie TJ, Jordan CE. 2007. Geomorphic changes upstream of beaver dams in Bridge Creek, an incised stream channel in the interior Columbia River basin, eastern Oregon. Earth Surface Processes and Landforms 32: 1174-1185.

Poole GC, O'Daniel SJ, Jones KL, Woessner WW, Bernhardt ES, Helton AM, Stanford JA, Boer BR, Beechie TJ. 2008. Hydrologic spiraling: The role of multiple interactive flow paths in stream ecosystems. River Research and Applications 24: 1018-1031.

Postel SL, Daily GC, Ehrlich PR. 1996. Human appropriation of renewable freshwater. Science 271: 785-788.

Richter BD, Thomas GA. 2007. Restoring environmental flows by modifying dam operations. Ecology and Society 12: 12. (31 December 2009; www.ecologyandsociety.org/vol12/iss1/art12/)

Richter BD, Warner AT, Meyer JL, Lutz K. 2006. A collaborative and adaptive process for developing environmental flow recommendations. River Research and Applications 22: 297-318.

Roni P, Hanson K, Beechie T. 2008. International review of effectiveness of stream rehabilitation. North American Journal of Fisheries Management 28: 856-890
Sear DA. 1994. River restoration and geomorphology. Aquatic Conservation 4: 169-177.

Sear DA, Arnell NW. 2006. The application of paleohydrology in river management. Catena 66: 169-183.

Sear DA, Kitts DR, Millington CE. 2006. The Geomorphic and Hydrological Response of New Forest Streams to River Restoration. New Forest LIFEIII Monitoring Report. Hampshire County Council. (31 December 2009; www.newforestlife.org.uk/life3/PDFs/PDFs/9.16Geomorphological MonitoringReport.pdf)

Sear DA, Wheaton J, Darby SE. 2008. Uncertain restoration and the role of geomorphology. Pages 739-762 in Habersack H, Piegay H, Rinaldo M, eds. Gravel Bed Rivers, IV: From Process Understanding to River Restoration. Elsevier.

Shafroth PB, Beauchamp V. 2006. Defining Ecosystem Flow Requirements for the Bill Williams River, Arizona. US Department of the Interior, US Geological Survey Open-File Report 2006-1314. (31 December 2009; www.fort.usgs.gov/products/publications/21745/21745.pdf )

Stanford JA, Ward JV, Liss WJ, Frissell CA, Williams RN, Lichatowich JA, Coutant CC. 1996. A general protocol for restoration of regulated rivers. Regulated Rivers: Research and Management 12: 391-413.

Stanford JA, Lorang MS, Hauer FR. 2005. The shifting habitat mosaic of river ecosystems. Verhandlungen des Internationalen Verein Limnologie 29: 123-136.

Stoddard JL, Larsen DP, Hawkins CP, Johnson RK, Norris RH. 2006. Setting expectations for the ecological condition of streams: The concept of reference condition. Ecological Applications 16: 1267-1276.

Syvitski JPM, Vörösmarty CJ, Kettner AJ, Green P. 2005. Impact of humans on the flux of terrestrial sediment yield to the global coastal ocean. Science 308: 376-380.

Tharme RE. 2003. A global perspective on environmental flow assessment: Emerging trends in the development and application of environmental flow methodologies for rivers. River Research and Applications 19: 397-441.

Tilman D, Fargione J, Wolff B, D'Antonio C, Dobson A, Howarth R, Schindler D, Schlesinger WH, Simberloff D, Swackhamer D. 2001. Forecasting agriculturally driven global environmental change. Science 292: 281-284

Trush WJ, McBain SM, Leopold LB. 2000. Attributes of an alluvial river and their relation to water policy and management. Proceedings of the National Academy of Sciences 97: 11858-11863.

Ward JV, Tockner K, Schiemer F. 1999. Biodiversity of floodplain river ecosystems: Ecotones and connectivity. Regulated Rivers: Research and Management 15: 125-139.

Ward JV, Tockner K, Arscott DB, Claret C. 2002. Riverine landscape diversity. Freshwater Biology 47: 517-539.

Wheaton J, Sear DA, Darby SE. 2008. The scope of uncertainty in river restoration. Pages 21-42 in Darby SE, Sear DA, eds. River Restoration: Managing the Uncertainty in Restoring Physical Habitat. Wiley.

Wohl E, Angermeier PL, Bledsoe B, Kondolf GM, MacDonnell L, Merritt DM, Palmer MA, Poff NL, Tarboton D. 2005. River restoration. Water Resources Research 41: W10301.

Yanes M, Velasco JM, Suarez F. 1995. Permeability of roads and railways to vertebrates: The importance of culverts. Biological Conservation 71: $217-222$.

Timothy J. Beechie (tim.beechie@noaa.gov), George R. Pess, and Michael M. Pollock are research fish biologists with the NOAA Fisheries Northwest Fisheries Science Center in Seattle. Philip Roni is the Watershed Program Manager at the Northwest Fisheries Science Center. David A. Sear is a senior lecturer at the School of Geography, University of Southampton, Hampshire, United Kingdom. Julian D. Olden is an assistant professor at the School of Aquatic and Fishery Sciences, at the University of Washington, Seattle. John M. Buffington is a research geomorphologist with the US Forest Service, Rocky Mountain Research Station, Boise, Idaho. Hamish Moir is a research geomorphologist with the Macaulay Institute, Craigiebuckler, Aberdeen, Scotland. 